Gut, 1974, 15, 805-811

\title{
Enzyme changes in human small bowel mucosa during culture in vitro
}

\author{
J. D. MITCHELL ${ }^{1}$, JUDith MITCHELL ${ }^{1}$, AND T. J. PETERS \\ From the Department of Medicine, Royal Postgraduate Medical School, London
}

SUMMARY Human jejunal biopsy slices were maintained in culture for up to 48 hours. At 24 hours there was good morphological preservation but by 48 hours there was ultrastructural evidence of damage to the enterocytes. During culture the tissue had lost a certain amount of protein. At the same time the levels of three brush border enzymes (alkaline phosphatase, $\alpha$-glucosidase, and leucyl- $\beta$-naphthylamidase) and one lysosomal enzyme ( $\mathrm{N}$-acetyl- $\beta$-glucosaminidase) showed a progressive decrease. Alkaline phosphatase, $\alpha$-glucosidase, and $\mathrm{N}$-acetyl- $\beta$-glucosaminidase accumulated in the medium throughout the experimental period to give a medium:tissue distribution ratio of between 2 and 9. Leucyl- $\beta$-naphthylamidase had a medium :tissue ratio of 140 after 48 hours of culture suggesting a selective secretion of this enzyme by the tissue.

Browning and Trier (1969) reported maintenance of the ultrastructural appearance of human small bowel mucosa during 24 hours of organ culture. More recently, a culture method in which tissue slices from intestinal biopsies were incubated in roller tubes has been shown to give similar results. This system was used to study the morphological changes that occur when tissue from cases of childhood coeliac disease was cultured with enzymic digests of wheat gliadin (Mitchell, Bhathal, Cornell, and Townley, 1972; Townley, Cornell, Bhathal, and Mitchell 1973).

As an alternative to morphological monitoring of the tissue during culture, Kagnoff, Donaldson, and Trier (1972) assayed certain disaccharidases in the culture tissue during studies with rabbit intestine. Because of the very limited amounts of tissue obtainable from peroral biopsy specimens, application of this biochemical approach to the assessment of human intestinal culture studies requires assay methods with greater sensitivity than those used by Kagnoff and his colleagues.

The aim of this study was to adapt sensitive fluorimetric micro-assay methods to investigate enzyme activities in cultures of human jejunal biopsy tissue, and to develop a reproducible, quantitative means of assessing subcellular changes in intestinal mucosal tissue.

${ }^{1}$ Present address : Department of Paediatrics, Prince of Wales Hospital, Randwick, NSW, Australia

Received for publication 3 July 1974

\section{Materials and Methods}

\section{BIOPSY SPECIMENS}

Biopsies were taken from the proximal jejunum with a Watson intestinal biopsy capsule. Specimens were obtained from five normal adult volunteers aged 27 to 33 years and from a 22-year-old male with Crohn's disease localized to the terminal ileum. The dissecting and light microscope appearances of all specimens were normal.

\section{CULTURE MEDIUM}

Eagle's basal medium containing Earle's salts (EBM) was used with $10 \%$ fetal calf serum (Tissue Culture Services Ltd, Slough, UK), penicillin (100 units $/ \mathrm{ml})$, and streptomycin $(100 \mu \mathrm{g} / \mathrm{ml})$. The EBM used for the initial collection, transport, and for the cleaning of the tissue was buffered with $20 \mathrm{mM}$ Hepes (Flow Labs, Irvine, UK) and that for the culture incubation was buffered with sodium bicarbonate (Difco Labs, Detroit, USA).

\section{CULTURE TECHNIQUE}

After biopsy, the specimen was placed immediately into a small petri dish (Falcon Plastics, California, USA) containing $5 \mathrm{ml}$ medium. Under the dissecting microscope a piece was taken for routine histology and the remainder divided with a sterile scalpel blade into four to six pieces, each with a volume of approximately $1 \mathrm{~mm}^{3}$. One slice was placed in $2 \mathrm{ml}$ SVE medium $(0.3 \mathrm{M}$ sucrose containing 805 
1 mM EDTA, pH 7.0, and $0.1 \%$ ethanol) and stored at $-15^{\circ} \mathrm{C}$ for baseline analysis.

Tissue slices were cleaned by allowing them individually to fall through a discontinuous density gradient of medium $(2 \mathrm{~cm})$ layered over fetal calf serum $(1 \mathrm{~cm})$ in a small test tube. Pipetting from the surface, the supernatant fluid was removed and the procedure was repeated. Individual slices were transferred to plastic culture tubes (Gallenkamp, London, UK) containing $1.0 \mathrm{ml}$ of medium and loosely covered with Oxoid caps. The tubes were rotated at 12 revolutions/hour on a drum roller in an incubator at $37^{\circ} \mathrm{C}$ with a continuous flow atmosphere of $95 \% \mathrm{O}_{2}$ and $5 \% \mathrm{CO}_{2}$. The time from the biopsy to the start of incubation was approximately one hour and cultures were terminated at various times up to $\mathbf{4 8}$ hours later.

Up to 11 individual tissue slices were incubated in each experiment. Samples of the culture medium were also incubated under identical conditions, so that corrections for the baseline levels of the enzymes in the culture medium could be made. At the end of culture, samples of medium were plated onto horse blood agar and examined for colony growth after $\mathbf{4 8}$ hours' aerobic incubation at $37^{\circ} \mathrm{C}$. The tissues were removed, washed gently in $1.0 \mathrm{ml}$ SVE medium, and transferred to a further $2.0 \mathrm{ml}$ SVE medium for homogenization and subsequent enzyme analysis. The $1.0 \mathrm{ml}$ SVE wash fluid was combined with the culture medium from the corresponding tissue and stored for later analysis. All assays were performed within 36 hours of completing the cultures.

\section{MORPHOLOGICAL STUDIES}

All biopsy samples were examined in EBM transport medium under a dissecting microscope at the time of intitial division into slices. All cultured tissue slices were again examined at the termination of incubation.

In addition, some unincubated control and cultured tissue slices were examined by light and electron microscopy. Tissues were fixed in glutaraldehyde and embedded in Araldite. Thick, $1 \mu \mathrm{m}$, sections were stained with toluidine blue and used to orientate the blocks to obtain representative thin sections for electron microscopy.

\section{ENZYME ANALYSIS}

Immediately before assay, the tissue specimens were homogenized in $2.0 \mathrm{ml}$ SVE medium with 30 strokes of a tight fitting type B pestle in a small Dounce homogenizer (Kontes Glass Co, Vineland, NJ, USA). All tissues and media from one experiment were handled as a batch for each assay and as far as possible all assays were performed within 48 hours of thawing and homogenization.

Alkaline phosphatase, $\alpha$-glucosidase, and $\mathrm{N}$ acetyl- $\beta$-glucosaminidase activities were estimated in duplicate using the fluorimetric method described by Peters, Müller, and de Duve (1972) and leucyl- $\beta$ naphthylamidase as described by Peters (1972). The $\mathrm{pH}$ optima and details of assay procedure are given in table I. Suitable enzyme and substrate blanks were performed with all assays. Assays in which the duplicate estimations varied by more than $10 \%$ were repeated. Enzyme activities in duplicate samples of control medium were assayed either immediately after preparation or after incubation at $37^{\circ} \mathrm{C}$ for up to 48 hours, and were found to remain constant. Therefore the average of the enzyme activities in the control medium samples of each experiment was used to correct the baseline activity in the culture medium.

Protein was determined on aliquots of tissue homogenates by a micromodification of the method of Lowry, Rosebrough, Farr, and Randall (1951) using bovine serum albumin (Armour Pharmaceuticals) as standard.

Enzyme activities were expressed in milliunits $(\mathrm{mU})$, one $\mathrm{mU}$ corresponding to the hydrolysis of 1 nanomole of substrate per minute at $37^{\circ} \mathrm{C}$. Results expressed as specific activities are mU units per milligrams protein determined in the same tissue slice.

SPECIFIC ACTIVITIES IN MULTIPLE SLICES OF A SINGLE BIOPSY

To establish the variation likely when assaying multiple slices of single biopsies using the present

\begin{tabular}{|c|c|c|c|}
\hline Enzyme & Substrate & pH Optimum & Buffer \\
\hline $\begin{array}{l}\text { Alkaline phosphatase } \\
\text { Leucyl- } \beta \text {-naphthylamidase } \\
\text { a-Glucosidase } \\
\text { N-Acetyl- } \beta \text {-glucosaminidase }\end{array}$ & $\begin{array}{l}4 \text { Methyl-umbelliferylphosphate } \\
\text { Leucyl-2-naphthylamide } \\
\text { 4-Methyl-umbelliferyl- } \\
\text { a-glucopyranoside } \\
\text { 4-Methyl-umbelliferyl-2-deoxy-2- } \\
\text { acetamido- } \beta \text {-glucopyranoside }\end{array}$ & $\begin{array}{l}9 \cdot 2 \\
7 \cdot 1 \\
6 \cdot 1 \\
5 \cdot 8\end{array}$ & $\begin{array}{l}0 \cdot 1 \mathrm{M} \mathrm{Na} \text { borate and } 10 \mathrm{mM} \mathrm{MgCl}_{\text {, }} \\
0 \cdot 1 \mathrm{M} \mathrm{Na} \text { phosphate } \\
0 \cdot 1 \mathrm{M} \mathrm{Na} \text { phosphate } \\
0 \cdot 1 \mathrm{M} \mathrm{Na} \text { acetate }\end{array}$ \\
\hline
\end{tabular}

Table I Conditions for fluorimetric enzyme assays

14-Methyl-umbelliferyl derivatives purchased from Koch-Light Laboratories Colnbrook, UK, and leucyl-2-naphthylamide from Sigma Chemical Co, St Louis, USA. Final substrate concentration $0.15 \mathrm{mM}$ in a volume of $0.35 \mathrm{ml}$. All buffer solutions contained $0.1 \%$ Triton $\mathrm{X} 100$. 


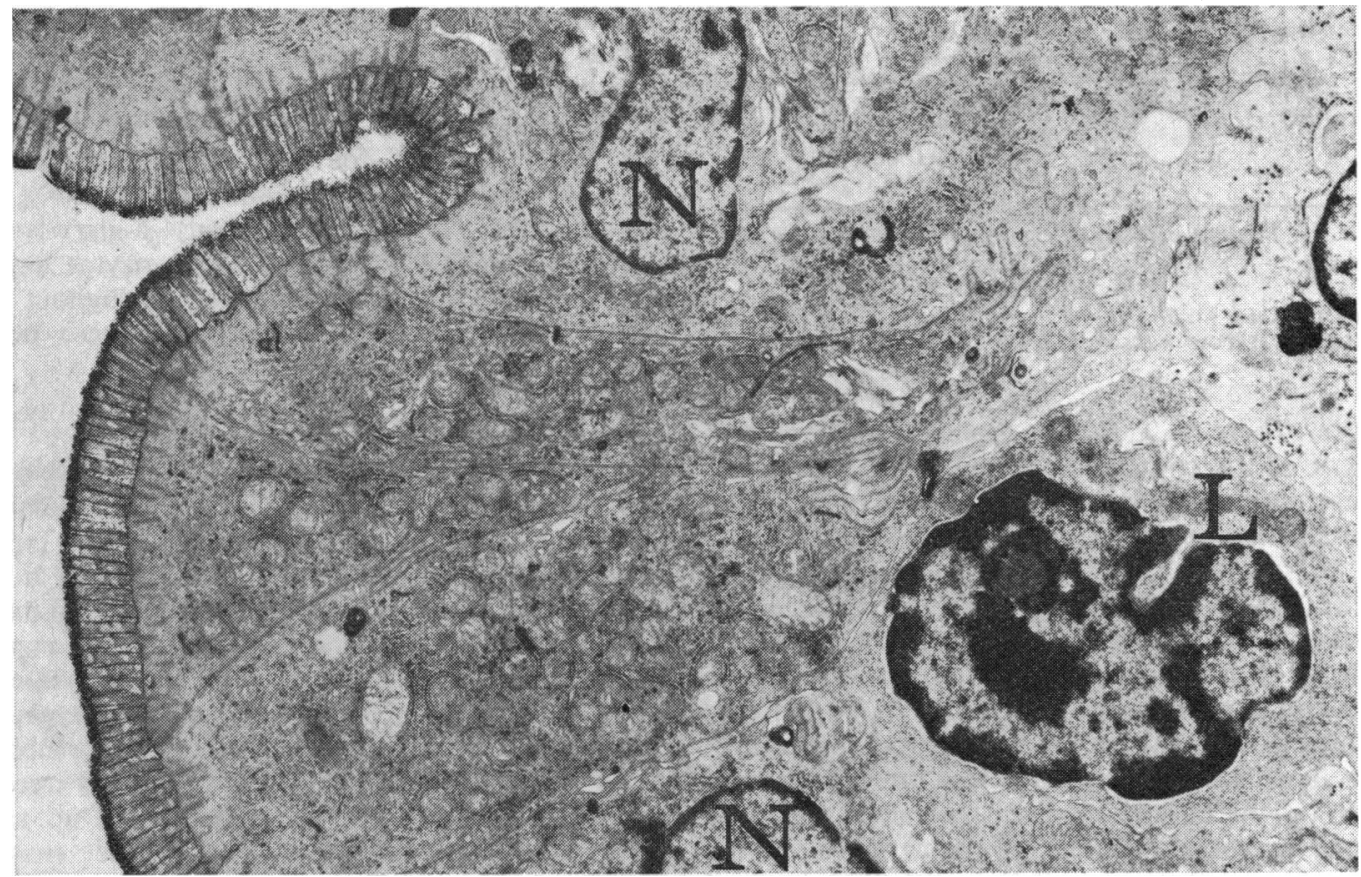

Fig 1 Ultrastructural appearance of jejunal mucosal slice cultured for 24 hours. A number of enterocytes with wellpreserved microvilli and intact organelles including nuclei $(N)$ are shown together with an intact lymphocyte $(L)$.

methods, five slices of one jejunal biopsy were homogenized and assayed separately. The mean \pm SD specific activity (mUnits/mg protein) for the three enzymes assayed were alkaline phosphatase $53 \cdot 7 \pm 11 \cdot 1 ; \alpha$-glucosidase $6 \cdot 18 \pm 0 \cdot 22$; $\mathrm{N}$-acetyl- $\beta$-glucosaminidase $2 \cdot 81 \pm 0 \cdot 10$. The deviation for alkaline phosphatase is thus greater than that for the other enzymes.

\section{ENZYME ACTIVITIES IN CULTURE MEDIUM}

It was necessary to correct the level of enzyme released from the biopsy for the basal level of activity in the culture medium. Ten samples of medium were assayed in duplicate for the following enzymes (mean \pm SD mUnits $/ \mathrm{ml}$ ): alkaline phosphatase, $1.54 \pm 0.20$; leucyl- $\beta$-naphthylamidase, $0.81 \pm 0.23 ; \alpha$-glucosidase, $0.020 \pm 0.004 ; \mathrm{N}$ acetyl- $\beta$-glucosaminidase, $0.64 \pm 0 \cdot 14$. Except for $\mathrm{N}$-acetyl- $\beta$-glucosaminidase these levels are low compared with the released enzyme.

\section{Results}

\section{MORPHOLOGY OF CULTURED TISSUES}

Dissecting microscopy of tissue slices showed a progressive reduction in the height of the villi during culture: however, the translucent rim of epithelial cells overlying the lamina propria was always recognizable and of comparable thickness to that seen in uncultured control or fresh normal tissue. Small blood vessels could usually be seen beneath the epithelial layer. A surrounding zone of mucus and debris developed and was more pronounced after longer periods of culture.

Light and electron microscopy performed on tissues after 24 hours' culture showed that although the villi were occasionally shorter, the ultrastructural appearance of cells of the epithelium and the lamina propria had been well preserved (fig 1). By 48 hours' culture there was, however, some evidence of damage to the enterocytes with blunting of the microvilli and early vacuole formation in the cytoplasm probably associated with swelling of the endoplasmic reticulum.

The dissecting microscopic appearance of the tissue from occasional cultures shown to be bacteriologically contaminated was quite distinct, developing either gross oedema and distortion of the villi or undergoing disintegration of the tissue to leave only a shell-like outline.

PROTEIN CONTENT OF CULTURED TISSUES

Table II shows the protein content of the tissue fragments before and after 12,24 , or 48 hours of 


\begin{tabular}{ll}
\hline $\begin{array}{l}\text { Culture Time } \\
\text { (hours) }\end{array}$ & $\begin{array}{l}\text { Protein Content } \\
(\mu \mathrm{g} / \mathrm{mg} \text { tissue })\end{array}$ \\
\hline 0 & $84 \cdot 0 \pm 15 \cdot 1(5)^{2}$ \\
12 & $51 \cdot 2 \pm 9 \cdot 9(5)$ \\
24 & $36 \cdot 5 \pm 4 \cdot 4(8)$ \\
48 & $29 \cdot 4 \pm 3.8(10)$ \\
\hline
\end{tabular}

Table II Protein content of control and cultured biopsy fragments

${ }^{1}$ Values are mean $\pm \mathrm{SE}$

Number of experiments shown in parentheses.

culture. There is a steady decline in the protein content of the cultured tissue so that by 48 hours' culture only about one-third of the protein in the original biopsy remains.

TOTAL ENZYME ACTIVITIES IN CULTURED TISSUE AND IN THE CULTURE MEDIUM

Table III shows the amount of four enzymes in the tissue and in the medium after $0,12,24$, or 48 hours of culture. Comparing the amount in the control piece from each biopsy with that in the cultured tissue and its culture medium (corrected for basal enzyme activity in culture medium) after varying culture times, there is a definite increase in total enzyme level in the system. The enzymes do, however, show a different response with alkaline phosphatase increasing threefold, leucyl- $\beta$-naphthylamidase 30 fold, $\alpha$-glucosidase 1.5 fold, and $\mathrm{N}$-acetyl $\beta$-glucosaminidase increasing twofold by 48 hours' culture. It is apparent that most of this increase occurs during the first $\mathbf{1 2}$ hours of culture.

When the tissue and medium are considered separately, there are differences in the enzyme changes during culture. With the exception of leucyl- $\beta$-naphthylamidase, which decreases in amount throughout the culture period in the cultured tissue, the enzyme content of the biopsy remains constant or even increases during the first 12 hours of culture. However, by 48 hours the levels had decreased to $32 \%$ for alkaline phosphatase, to $24 \%$ for leucyl- $\beta$-naphthylamidase, to $44 \%$ for $\alpha$-glucosidase, to $31 \%$ for $\mathrm{N}$-acetyl- $\beta$-glucosaminidase, and to $32 \%$ for protein. The enzyme level in the culture medium increases throughout the experiment although the greatest increase occurs during the first 12 hours.

\section{NATURE OF RELEASED ENZYMES}

Certain studies were performed on the nature of the enzymes released into the culture media. Similar pH optima were obtained for both tissue and culture media. Centrifugation of the media and of homogenized tissue samples was carried out for $20 \mathrm{~min}$ at $20000 \mathrm{~g}$ and the percentage enzyme activity capable of sedimentation was determined. In the tissue approximately $75 \%$ of the activity was sedimented but in the medium only $5 \%$. Samples of culture medium from which the biopsies had been removed were incubated at $37^{\circ} \mathrm{C}$ for additional periods up to 48 hours and the levels of the four marker enzymes reassayed. No significant change in activity was noted, indicating that no inactivation of the released enzymes or activation of a proenzyme occurred in the culture medium.

\section{ENZYME SPECIFIC ACTIVITIES IN TISSUE}

Figure 2 shows the specific activity of the four enzymes in the tissue after varying periods of culture. The graphs show the results from three individual biopsies. There is a decrease in specific activity of leucyl- $\beta$-naphthylamidase during culture but no consistent change was noted for the other

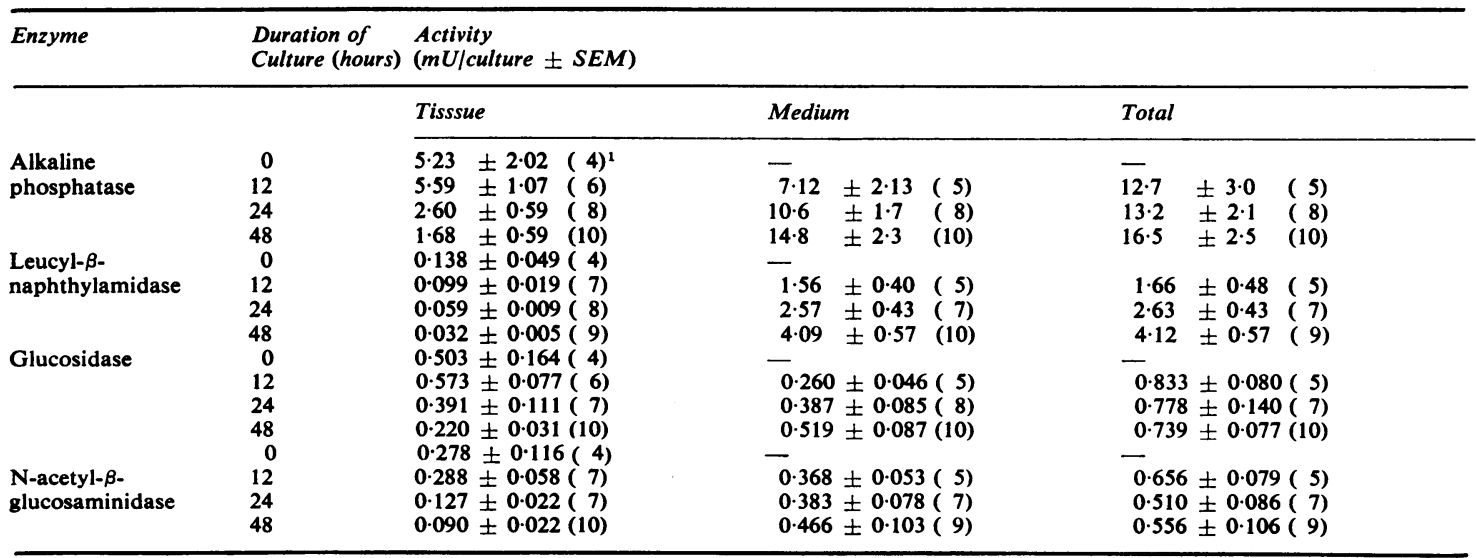

Table III Enzyme activities of cultured biopsies and corrected enzyme activities of culture medium Number of samples shown in parentheses. 


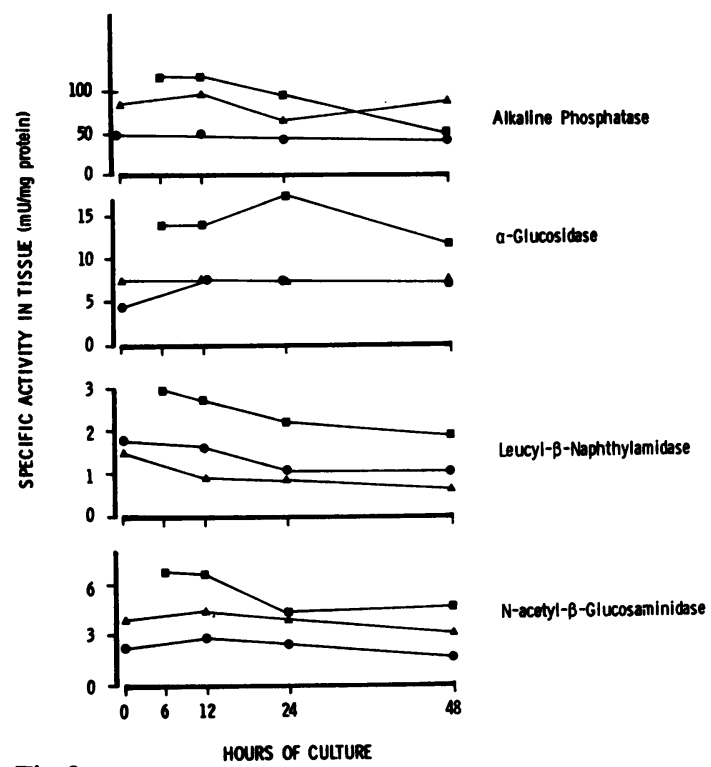

Fig 2

Fig 2 Specific activities of four enzymes in jejunal biopsy tissue slices cultured for up to 48 hours. Three separate experiments are shown by different symbols. Each point represents the mean value of two or more cultures.

Fig 3 Accumulation of enzyme activities in culture medium expressed in relation to the activity in the tissue slice. Each point represents the mean value of up to five experiments.

enzymes. These results are in agreement with the data shown in table II where a total loss of protein from the biopsy of approximately $30 \%$ was paralleled by a similar loss of all enzymes, excepting leucyl- $\beta$-naphthylamidase. The specific activity of these three enzymes remains constant but leucyl $\beta$ naphthylamidase decreases in the biopsy by more than $30 \%$ and thus there is a decline in specific activity of this enzyme.

\section{CULTURE MEDIUM:TISSUE ENZYME DISTRI- BUTION}

Figure 3 shows the ratio of specific activities in the biopsy and in the culture medium of individual biopsies which permits a comparison of the release of the individual enzymes from the tissue. Little release of any enzyme occurs during the first six hours of culture. However, during the following 42 hours there is a massive release of leucyl- $\beta$ naphthylamidase which reaches a medium:tissue ratio of 140. Alkaline phosphatase achieved a distribution ratio of 9 whereas the third brush

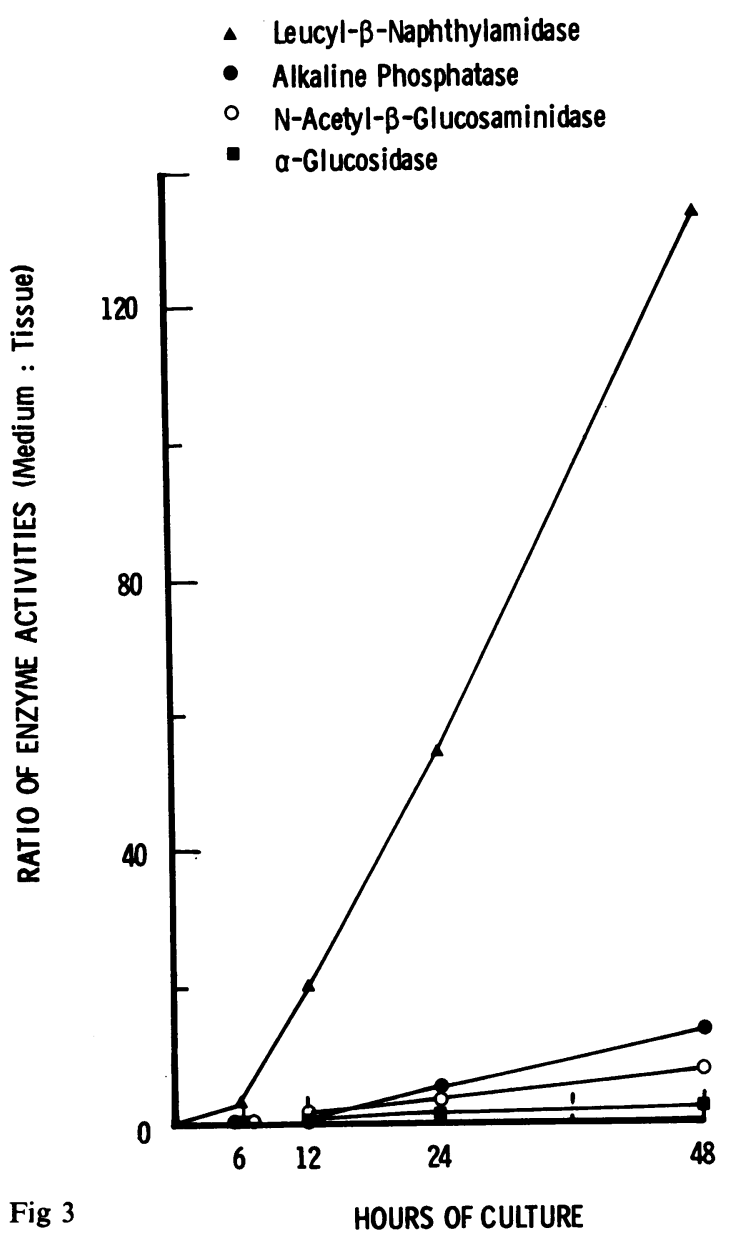

Fig 3

border enzyme studied, $\alpha$-glucosidase, has a final distribution ratio of 2 . The lysosomal enzyme reached a distribution ratio of 5 .

\section{Discussion}

The data in this paper demonstrate for the first time that there is a specific release of enzymes by cultured human intestinal mucosa into the surrounding medium. They also provide basic information on the kinetics of enzyme activities during culture of normal intestinal mucosa in vitro and will form the background against which similar studies on coeliac mucosa will be performed. The morphological findings indicated, as in previous studies (Townley et al, 1973) and in those of other workers (Browning and Trier, 1969; Falchuk, Gebhard, Sessoms, and Strober, 1974), that cell ultrastructure is well preserved. The culture period 
in the present study was extended to 48 hours and there was some evidence of damage to the enterocyte.

Marker enzymes for the brush border of the enterocyte (alkaline phosphatase, leucyl- $\beta$-naphthylamidase, and $\alpha$-glucosidase) were assayed as morphological studies had indicated that this region of the cell is damaged in coeliac disease (see Booth, 1970). Similarly, the lysosomal marker enzyme, $\mathrm{N}$-acetyl- $\beta$-glucosaminidase (Peters, 1972, 1973), was assayed in these experiments as there is evidence that change also occurs in these organelles in the enterocytes during the development of coeliac disease (Riecken, Stewart, Booth, and Pearse, 1966; Peters, Doe, Heath, and Mitchell, 1972; Townley, et al, 1973).

The observation that the total enzyme content of the tissue and medium increases during culture is in agreement with studies using labelled amino acids that intestinal mucosa is capable of protein synthesis in culture (Loeb, Strober, Falchuk, and Laster, 1971; Kagnoff et al, 1972; Warshaw and Laster, 1973).

It is unlikely that this increased enzyme activity represents the release of latent enzyme activity as the detergent Triton X100 was included in all assays. However, more detailed studies would be necessary to prove rigorously that synthesis of each of these enzymes had occurred de novo.

Although the morphological studies indicate ultrastructural preservation for at least 24 hours of culture, the biochemical studies performed in parallel indicate a progressive loss of protein from the tissue. This loss may in part represent release (either intact or fragments thereof) of damaged enterocytes and other mucosal cells. It is, however, unlikely that damage to the tissue is the sole cause of the enzyme release. The strikingly. different behaviour of the different enzymes, even between the three enzymes derived from the brush border, does not support the hypothesis of non-specific damage to cells with consequential release of their enzyme components. The demonstration that the brush border marker enzymes released into the medium are almost entirely incapable of being sedimented compared with their state in the intact tissue is also inconsistent with the shedding of large quantities of cells or their constituent organelles into the culture medium.

It is surprising that the three brush border enzymes (alkaline phosphatase, $\alpha$-glucosidase, and leucyl- $\beta$-naphthylamidase) show such widely different rates of release into the culture medium. This may reflect the substructure of the microvillus membrane as postulated by Eichholz (1967) or differing turnover rates of different brush border components (Alpers, 1972). The different response of these enzymes is not due to differences in the rate of their degradation in the culture medium as no significant loss of any of these enzymes occurred on incubating the culture medium alone. The release of leucyl- $\beta$-naphthylamidase into the culture medium is particularly striking and reaches a medium: tissue ratio at least 10 times that of the other enzymes studied. This observation, coupled with marked decrease in tissue content, would suggest that this enzyme is selectively secreted into the medium.

The level of the lysosomal marker enzyme Nacetyl- $\beta$-glucosaminidase in the tissue also decreases throughout the period of culture. The level of enzyme in the culture medium increases during the experiment but unlike the brush border enzymes most of this increase occurs during the first 12 hours with a much smaller rise during the following 36 hours. This activity released during the early culture period probably represents activity from sloughed cells as it should be noted that all cells of the biopsy, including the lymphoid cells, contain significant levels of lysosomal enzymes (Bowers, Finkenstaedt, and de Duve, 1967) whereas the brush border enzymes are largely confined to the enterocytes. Although these studies do not demonstrate clearly the secretion of lysosomal enzymes by the enterocytes it is highly likely that they contribute significantly to this released enzymic activity. In this context it is worth recalling that release of lysosomal enzymes occurs from several cell types during the uptake or extrusion of material across the cell membrane (see Henson, 1972).

Kagnoff et al (1972) expressed the enzyme levels in their cultured biopsies as units of activity per milligram protein. As demonstrated in this paper this can lead to misinterpretations. Thus when protein loss parallels the loss of enzyme the specific activity will remain constant throughout the period of culture.

The present study also demonstrates the importance of assaying activities in the culture medium; by 48 hours between 70 and $95 \%$ of the enzyme activity in the culture tube is recovered in the medium. A number of implications emerge from this work. Recent studies (Moss, Lobley, and Holmes, 1972; Gotze, Adelson, Hadorn, Portman, and Troesch, 1972; Dyck, Hall, and Ratliff, 1973; Kedinger, Berteloot, and Hugon, 1973) have indicated that a hormone-mediated release of brush border enzymes into the intestinal lumen occurs. The culture system may prove a useful technique for investigating this phenomenon.

If enzymes from the brush border are similarly released in vivo, high levels must be expected to be found in the lumen. It is possible that released 
enzymes remain within the glycocalyx or in the unstirred layer surrounding the brush borders. This retention of digestive enzymes within the microenvironment of the brush border is in keeping with the concept of membrane digestion (Ugolev, 1965).

This synthesis-degradation and secretion of many components by the intestinal mucosa-including proteins, nucleic acids, chylomicrons, immunoglobulins, and various gastrointestinal hormonescan readily be studied. The reproducibility of the enzyme assays obtained indicates that detailedenzyme studies on pathological tissue can be undertaken and in particular possible models of gluten-induced enteropathy might be set up. More quantitative assessment of the toxicity of gluten fractions might be made than are at present possible using morphological methods.

The encouragement and helpful advice of Professor C. C. Booth and Dr W. F. Doe is acknowledged. We are particularly grateful to Miss J. R. Heath for her expert technical assistance. This study was in part supported by the Wellcome Foundation and Medical Research Council grants to $\mathrm{Dr}$ T. J. Peters. Dr J. D. Mitchell was supported by a Commonwealth medical fellowship.

\section{References}

Alpers, D. H. (1972). The relation of size to the relative rates of degradation of intestinal brush border proteins. J. clin. Invest., 51, 2621-2630.

Booth, C. C. (1970). The enterocyte in coeliac disease. Brit. med. J., 3, 725-31.

Bowers, W. B., Finkenstaedt, J. T., and de Duve, C. (1967). Lysosomes in lymphoid tissue. I. The measurement of hydrolytic activities in whole homogenates. J. Cell Biol., 32, 325-337.

Browning, T. H. and Trier, J. S. (1969). Organ culture of mucosal biopsies of human small intestine. J. clin. Invest., 48, 1423-1432.

Dyck, W. P., Hall, F. F., and Ratliff, C. R. (1973). Hormonal control of intestinal alkaline phosphatase secretion in the dog. Gastroenterology, 65, 445-450.

Eichholz, A. (1968). Studies on the organisation of the brush border in intestinal epithelial cells. V. Subfractionation of enzymatic activities of the microvillus membrane. Biochim. biophys. Acta (Amst.), 163, 101-107.

Falchuk, Z. M., Gebhard, R. L., Sessoms, C., and Strober, W. (1974). An in vitro model of gluten-sensitive enteropathy. Effect of gliadin on intestinal epithelial cells of patients with gluten-sensitive enteropathy. Effect of gliadin on intestinal epithelial cells of patients with gluten-sensitive enteropathy in organ culture. J. clin. Invest., 53, 487-500.

Götze, H., Adelson, J. W., Hadorn, N. B., Portmann, R., and Troesch, V. (1972). Hormone-elicited enzyme release by the small intestinal wall. Gut, 13, 471-476.

Henson, P. (1972). Pathologic mechanisms in neutrophil-mediated injury. Amer. J. Path., 68, 593-612.

Kagnoff, M. F., Donaldson, R. M., and Trier, J. S. (1972). Organ culture of rabbit small intestine: prolonged in vitro steady state protein synthesis and secretion and secretory IgA secretion. Gastroenterology, 63, 514-551.

Kedinger, M., Berteloot, A., and Hugon, J. S. (1973). Ultracytochemical study of adult guinea pig duodenal explants cultured for 24 hours. (Abstr.) J. Cell Biol., 59, 164a.

Loeb, P. M., Strober, W., Falchuk, Z. M., and Laster, L. (1971). Incorporation of $\mathrm{L}$ leucine $-{ }^{14} \mathrm{C}$ into immunoglobulins by jejunal biopsies of patients with celiac sprue and other gastrointestinal diseases. J. clin. Invest., 50, 559-569.

Lowry, O. H., Rosebrough, N. J., Farr, A. L., and Randall, R. J. (1951). Protein measurement with the Folin-phenol reagent. J. biol. Chem., 193, 265-275.

Mitchell, J. D., Bhathal, P. S., Cornell, H., and Townley, R. R. W. (1972). Gluten enteropathy in vitro: a culture system for the study of coeliac disease. Gut, 13, 848 .

Moss, S., Lobley, R. W., and Holmes, R. (1972). Enterokinase in human duodenal juice following secretin and pancreozymin and its relationship to bile salts and trypsin. Gut, 13, 851.

Peters, T. J. (1972). Subcellular fractionation of the enterocyte with special reference to peptide hydrolases. In Peptide Transport in Bacteria and Mammalian Gut: A Ciba Foundation Symposium, pp. 107-122. Elsevier, Amsterdam.

Peters, T. J. (1973). Subcellular fractionation of isolated rat jejunal enterocytes with special reference to lysosomes and peroxisomes. (Abstr.) Europ. J. clin. Invest., 3, 261.

Peters, T. J., Doe, W. F., Heath, J. R., and Mitchell, J. D. (1973). Lysosomal acid hydrolase activity in intestinal biopsies from control subjects and patients with coeliac disease. Gut, 14, 430.

Peters, T. J., Müller, M., and de Duve, C. (1972). Lysosomes of the arterial wall. I. Isolation and subcellular fractionation of cells from normal rabbit aorta. J. exp. Med., 136, 1117-1136.

Riecken, E. O., Stewart, J. S., Booth, C. C., and Pearse, A. G. E. (1966) A histochemical study on the role of lysosomal enzymes in idiopathic steatorrhoea before and during a gluten-free diet. Gut, 7, 317-332.

Townley, R. R. W., Bhathal, P. S., Cornell, H. J., and Mitchell, J. D. (1973). Toxicity of wheat gliadin fractions in coeliac disease. Lancet, 1, 1363-1364.

Ugolev, A. M. (1965). Membrane (contact) digestion. Physiol. Rev., $45,555-595$.

Warshaw, A. L., and Laster, L. (1973). Protein synthesis by human intestinal mucosa: variations with diseases of the gut. J. surg. Res., 14, 285-293. 